\title{
Life cycles and feeding habits of Syngnathus taenionotus and S. abaster (Pisces, Syngnathidae) in a brackish bay of the Po River Delta (Adriatic Sea)
}

\author{
P. Franzoi ${ }^{1}$, R. Maccagnani ${ }^{2}$, R. Rossi ${ }^{1}$, V. U. Ceccherelli ${ }^{2}$ \\ ${ }^{1}$ Department of Environmental Science, University of Tuscia, via C. De Lellis, I-01100 Viterbo, Italy \\ ${ }^{2}$ Department of Evolutionary Biology, University of Ferrara, via L. Borsari 46, I-44100 Ferrara, Italy
}

\begin{abstract}
We investigated the population structure, life cycles and gut contents of 2 species of pipefish, Syngnathus taenionotus and $S$. abaster, in a brackish embayment of the Po River Delta (North Adriatic Sea). These 2 species inhabit the nearshore environment of the bay where the sandy bottom is covered by macroalgae, and were sampled for $1 \mathrm{yr}$. The main differences in life history traits between $S$. taenionotus and $S$. abaster respecitvely can be summarized as follows: life span is about 24 vs 17 mo; reproductive season begins in February vs March, and lasts 5 vs 4 mo; average length of fingerlings at the time they hatch from the male brood pouch is $20.3( \pm 1.2)$ vs $13.5( \pm 1.0) \mathrm{mm}$; egg incubation period is $2 \mathrm{mo}$ vs $1 \mathrm{mo}$; average number of ripe eggs per mature ovary is 46 ( \pm 9 ) vs $104( \pm 40$ ); average number of embryos incubated by male is $84( \pm 17)$ vs $109( \pm 27)$. Finally, the sex ratio in the reproductive population is more male-biased in $S$. taenionotus than in $S$. abaster. The 2 species probably do not compete for food resources, remaining almost completely segregated in 2 different foraging micro-habitats during most of their life span. The new-born spring individuals of both species feed almost exclusively on harpacticoids of the genus Tisbe. As they mature, $S$. abaster continue to prey on phytal organisms while the larger $S$. taenionotus become zooplanktivorous.
\end{abstract}

\section{INTRODUCTION}

Shore fish communities are an important component of deltaic shallow water brackish environments. During the warm season this habitat is occupied by large numbers of small fishes, both juveniles of several migratory species, which use these brackish bays as nursery ground, and resident species (Quignard 1984). The latter are usually characterized by small size, short life cycle, one or few reproductive seasons, and increased parental care.

Pipefish of the Syngnathidae familiy are among the most typical representatives of these fish communities. During community studies (Ferrari \& Chieregato 1981, Ferrari \& Rossi 1983, Maccagnani et al. 1985, Rossi 1986, Franzoi et al. 1989) carried out on a brackish embayment of the Po River Delta, the Sacca di Scardovari, 2 species of pipefishes were often found together, both with relatively high abundance values: Syngnathus taenionotus Canestrini, 1871 and Syngnathus abaster L., 1758. Characteristic of the Syngnathidae life cycle is the male parental care. Males develop 2 skin folds ventrally, which merge into a brood pouch. Here, eggs and embryos are first inseminated and then incubated until they reach independence. For this reason, syngnathids have been considered interesting and important subjects in the study of sex role reversal, mate choice, and parental energy investment (Berglund et al. 1986a, b, 1988, 1989, Svensson 1988, Steffe et al. 1989, Berglund 1991, Vincent et al. 1992).

Another extensively investigated aspect of the pipefishes' life history has been their foraging ecology. They are gape-limited pipette-feeders with specialised predatory strategies (sit-and-wait or slow-search behaviour) (Ryer \& Boehlert 1983, Howard \& Koehn 1985, Main 1985, Ryer \& Orth 1987, Ryer 1988, Tipton \& Bell 1988, Steffe et al. 1989). However, little is known about pipefish biology and ecology in the Adriatic. In this 
study, population structures, life cycles and feeding habits of Syngnathus taenionotus and S. abaster have been investigated in order to describe differences in how these congeneric species exploit the same environment.

\section{MATERIALS AND METHODS}

Study area. The Sacca di Scardovari is a bay of about $32 \mathrm{~km}^{2}$, located in the southern part of the Po Delta. It is connected southwards to the sea by a mouth barred by partly submerged sand banks. The embayment consisted of 2 zones with clear differences in hydrodynamic and trophic features (Colombo et al. 1979). Water renewal in the northern area is more sluggish than in the southern one, which is directly influenced by tidal currents and water flow from the terminal branches of the river. This pattern is also reflected by overall sediment distribution inside the bay, with finer particles covering the bottom of the inner part of the embayment.

Three sampling stations were chosen within the bay across the southern and northern basins. The bottom is sandy at all 3 stations as a consequence of their nearshore location, and is covered by thick macroalgae beds (Ulva sp., Gracilaria sp.), especially during the warm season.

As expected, both temperature and salinity were extremely variable in this environment. It is important to stress that the very low water temperatures during the winter months (from 4.0 to $5.5^{\circ} \mathrm{C}$ in January 1982) may have caused fishes to find shelter in deeper, warmer waters.

Sampling and data analysis. From June 1981 to July 1982, sampling was carried out 19 times at almost monthly intervals (fortnightly in April, May, June and July) at the 3 stations.

Sampling was performed with a $60 \mathrm{~m}$ long beach seine, with a $6 \mathrm{~m}$ high central stretch, made of $2 \mathrm{~mm}$ mesh-size net. Maximum sampling depth was $1.5 \mathrm{~m}$, i.e. the height of the poles keeping the seine's wings open when it was hand-trawled towards the beach, starting at about 40 to $50 \mathrm{~m}$ from the shore. Fishes were killed in a solution of chlorobutano and preserved in $10 \%$ formalin. Back in the laboratory they were transferred into $5 \%$ neutralized formalin for long-term preservation.

Syngnathus taenionotus and $S$. abaster were easily distinguished by the shapes of their snouts (Fig. 1): in $S$. taenionotus it is longer than in S. abaster (Dawson 1986). S taenionotus was classified based on characters such as the head dorsolateral profile, which, in contrast to S.acus, is not markedly elevated in the postorbital part (D'Ancona 1934, Dawson 1986) (Fig. 1), the number of subdorsal rings, the number of pre-anal rings and especially the number of post-anal rings. Indeed, all these are the main characters which distinguish Syngnathus taenionotus from $S$. acus (Table 1), a species that could be misclassified as $S$ taenionotus.

The standard length ( $\mathrm{SL} \pm 1 \mathrm{~mm}$ ) of every specimen was measured by an ichthyometer when the sample involved less than 500 specimens; otherwise stratified random subsamples of 500 individuals were used.

The number of ripe eggs in the ovaries were counted in a sample of 60 fully mature females per species. In these females, the whole gonad was also checked to assess the eggs' ripening. Diameters of a total of 60 eggs from 3 females per species were measured. In a sample of 60 males with full brood pouches from each species, the eggs or embryos they were carrying were counted. The total lengths of 35 newly hatched juveniles per species were measured.

For each species, the standard length range and proportion of individuals per cohort were obtained by resolving each monthly polymodal length frequency distribution of measured specimens in the single guassian components (Abramson 1971).

Gut content analysis. Analysis of the contents of the digestive tract was performed on 12 subsamples, grouping specimens of the 2 species into 3 seasons (spring: from June 1981 and 1982; summer: from July and August 1981; autumn: from September and October 1981) and 2 age-groups (0-age and 1 -age cohorts). Each subsample consisted of 30 full-gut contents (empty guts occasionally found were replaced by others), except in the case of autumn subsamples of 
Table 1. Syngnatus taenionotus. Some meristic measurements of specimens from Sacca di Scardovari compared with those for the same species from Venice Lagoon by D'Ancona (1934) and for S. acus (a species which could be misclassified as S. taenionotus) reported both by D'Ancona (1934) and Dawson (1986) (I): modal class). TL: total length

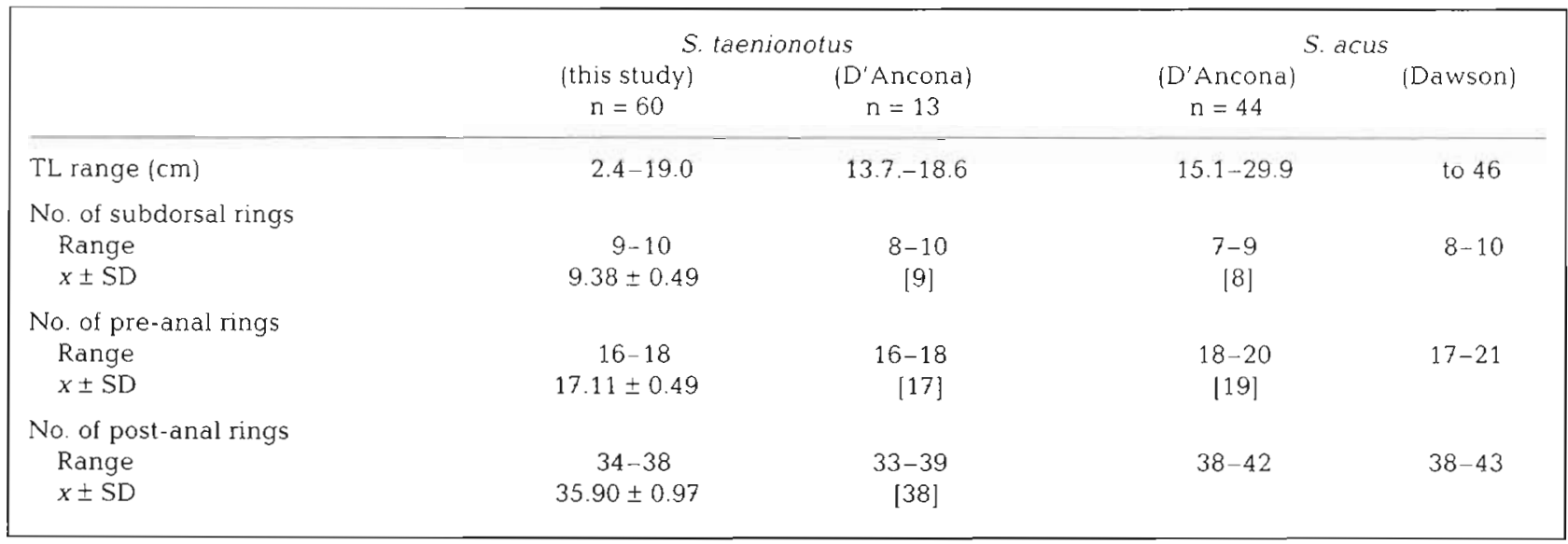

Syngnathus taenionotus, in which only 6 full guts of 0 -age and 11 of 1 -age groups were found. Food items were classified at species level when possible, and counted. Prey species were pooled into 'guilds', corresponding to the microhabitats in which they dwell. Moreover, food items within each guild were kept discrete in 2 arbitrary size categories.

We recognized the following guilds and size categories:

SED = small-sized species living in the sediments (e.g. harpacticoids)

SED + = large-sized species living in the sediments (e.g. corophids)

PHT = small-sized phytal animals (mainly harpacticoids)

PHT $+=$ large-sized phytal animals (e.g. gammarids, isopods)

MIX = small-sized epibenthic organisms living on the bottom but able to migrate transitorily into the water column (e.g harpacticoids)

MIX + = large-sized epibenthic organisms (e.g. palemonids)

PLN = small-sized planktonic organisms (e.g. calanoids, zoeae)

PLN + = large-sized planktonic organisms (mainly mysids)

PSC = occasionally found post-larval stages of fish.

Average abundance values and the corresponding relative abundances per guild $\left(p_{i}\right)$ were then calculated. A cluster analysis of the age/season subsamples of both pipefish species was performed, calculating a Horn's overlap index similarity matrix between paired subsamples. Horn (1966) proposed his measurement of overlap, $R_{0}$, derived from information theory, as the appropriate index when one is more interested in the overlap in foraging habitat than the overlap in exploi- tation of alternative food items from within the same habitat. The computational formula is as follows:

$R_{0}=\left[\Sigma\left(p_{i j}+p_{i k}\right) \ln \left(p_{i j}+p_{i k}\right)-\Sigma p_{i j} \ln p_{i j}-\Sigma p_{i k} \ln p_{i k}\right] / 2 \ln 2$

where $p_{i j}=$ proportion prey guild $i$ is of the total prey guilds of subsample $j ; p_{i k}=$ propotion prey guild $i$ is of the total prey guilds of subsample $k$.

A dendrogram was drawn using the flexible classification algorithm of Lance \& Williams (1967) with $\beta=-0.25$.

\section{RESULTS}

A total of 13898 specimens of Syngnathus taenionotus and 3924 of Syngnathus abaster were caught (Table 2). Populations of both species were far more abundant during the warm season, when they reproduce. The low figures recorded in autumn and winter are likely due to fishes having migrated to warmer, deeper water

\section{Length irequency distributions}

Fig. 2 shows the monthly size frequency distribution of both species. Months in which the number of specimens was less than 10 are not reported. For both species, the occurrence of 2 cohorts per year is evident. By analysis of length frequency distributions, it was possible to distinguish the recruit's cohorts (0-age) and the parent's cohorts (1-age and probably 2 -age). In accordance, specimens of Syngnathus taenionotus with a standard length (SL) less than $10.5 \mathrm{~cm}$ have been considered 0 -age, as have those of $S$. abaster with SL less than $8.0 \mathrm{~cm}$ 
Table 2. Number of specimens of Syngnathus species caught at each station in the Sacca di Scardovari. '(2)' means 2 samples per month

\begin{tabular}{|c|c|c|c|c|c|c|c|c|}
\hline & \multicolumn{4}{|c|}{ S. taenionotus } & \multicolumn{4}{|c|}{ S. abaster } \\
\hline & Stn 1 & Stn 2 & $\operatorname{Stn} 3$ & Total & Stn 1 & $\operatorname{Stn} 2$ & Stn 3 & Total \\
\hline Jun 1981 (2) & 247 & 6357 & 134 & 6738 & 63 & 186 & 27 & 276 \\
\hline Jul 1981 (2) & 520 & 3511 & 2394 & 6425 & 336 & 467 & 352 & 1155 \\
\hline Aug 1981 & 19 & 14 & 42 & 75 & 4 & 2 & 25 & 31 \\
\hline Sep 1981 & 0 & 2 & 13 & 15 & 204 & 2 & 8 & 214 \\
\hline Oct 1981 & 2 & 6 & 0 & 8 & 6 & 16 & 0 & 22 \\
\hline Nov 1981 & 0 & 0 & 0 & 0 & 0 & 0 & 1 & 1 \\
\hline Dec 1981 & 0 & 0 & 0 & 0 & 0 & 0 & 0 & 0 \\
\hline Jan 1982 & 0 & 0 & 1 & 1 & 0 & 0 & 0 & 0 \\
\hline Feb 1982 & 0 & 0 & 1 & 1 & 0 & 2 & 0 & 2 \\
\hline Mar 1982 & 0 & 0 & 2 & 2 & 0 & 0 & 2 & 2 \\
\hline Apr $1982(2)$ & 21 & 0 & 31 & 52 & 4 & 1 & 4 & 9 \\
\hline May 1982 (2) & 346 & 13 & 81 & 440 & 20 & 20 & 7 & 47 \\
\hline Jun 1982 (2) & 57 & 2 & 72 & 131 & 32 & 863 & 217 & 1112 \\
\hline Jul 1982 & 1 & 4 & 5 & 10 & 394 & 613 & 46 & 1053 \\
\hline Total & 1213 & 9909 & 2776 & 13898 & 1063 & 2172 & 689 & 3924 \\
\hline
\end{tabular}

The 0 -age cohorts of both species first occurred in May. Recruitment of Syngnathus taenjonotus continued until the end of September (although 2 specimens out of 8 sampled in October were of about $2 \mathrm{~cm}$ in length). Recruitment terminated in August for $S$. abaster.

The largest specimens (from 17.5 to $19 \mathrm{~cm}$ ) of Syngnathus taenionotus were found in April 1982. The following month (May 1982), no individual exceeding $17.5 \mathrm{~cm}$ was found. On the other hand, specimens up to $21.4 \mathrm{~cm}$ SL were caught in shore water of the Po Delta in July 1991 (Franzoi pers. obs.). Probably, the abovementioned April 1982 specimens had survived the winter twice. This suggests a life span of at least 24 mo.

In Syngnathus abaster the parental cohort seemed to disappear almost completely after September, thus indicating a life span of about $17 \mathrm{mo}$.

\section{Life cycles}

Life history parameters inferred from both direct observation and the above analysis of population structures are summarized separately for each species (Table 3). Their life cycles are as follows:

Syngnathus taenionotus. The reproductive season begins in February. In fact, the only specimen sampled that month (Table 2) was a female with ripe ovaries. Similarly, the only 2 specimens caught in March (Table 2) were males with brood pouches containing eggs. Mature females disappeared from samples after July, while breeding males disappeared after August. Newly-born fish appeared in the population in May, and were still present in September (also October).
Hence, the reproductive season appears to last about $5 \mathrm{mo}$. The time lag from both the first occurrence of breeding males (March) to the first occurrence of juveniles (May) and the last occurrence of mature females (July) to the last occurrence of juveniles (September) suggest an incubation time of about 2 mo. Peak abundance of the 0 -age cohort occurred in June-July, however.

The average percentage of females in the adult population ( $>10.5 \mathrm{~cm} \mathrm{SL}$ ) was $46.4 \%$ and the sex ratio did not significantly differ from a 50:50 ratio $\left(x^{2}=\right.$ 0.852, not significant at $1 \mathrm{df}$ ). However, during the peak of reproductive activity, in April-May, Syngnathus taenionotus showed a sex ratio favouring males (April: 5.4 males per female, $\chi^{2}=19.34, p<0.001$ at $1 \mathrm{df}_{\text {; May: }} 7.8$ males per female, $\chi^{2}=40.19, \mathrm{p}<0.001$ at $1 \mathrm{df}$ ).

The average number of embryos per male was about twice that of ripe eggs per female. Theoretically, each male is able to simultaneously incubate the eggs from at least 2 females.

Microscopical observation of the ovaries showed that, besides the relatively small number of actually ripe eggs, there was also a continuous series of oocytes and eggs at several different ripening stages.

Syngnathus abaster. The reproductive season begins in March; the 2 adults caught in February were not sexually mature, while the 2 specimens sampled in March were mature females (Table 3); males with brood pouches containing eggs/embryos were caught from the beginning of April. Mature females and breeding males disappeared from the samples after July. Newly hatched fishes appeared in the population in May and were present until August. The reproduc- 
a)
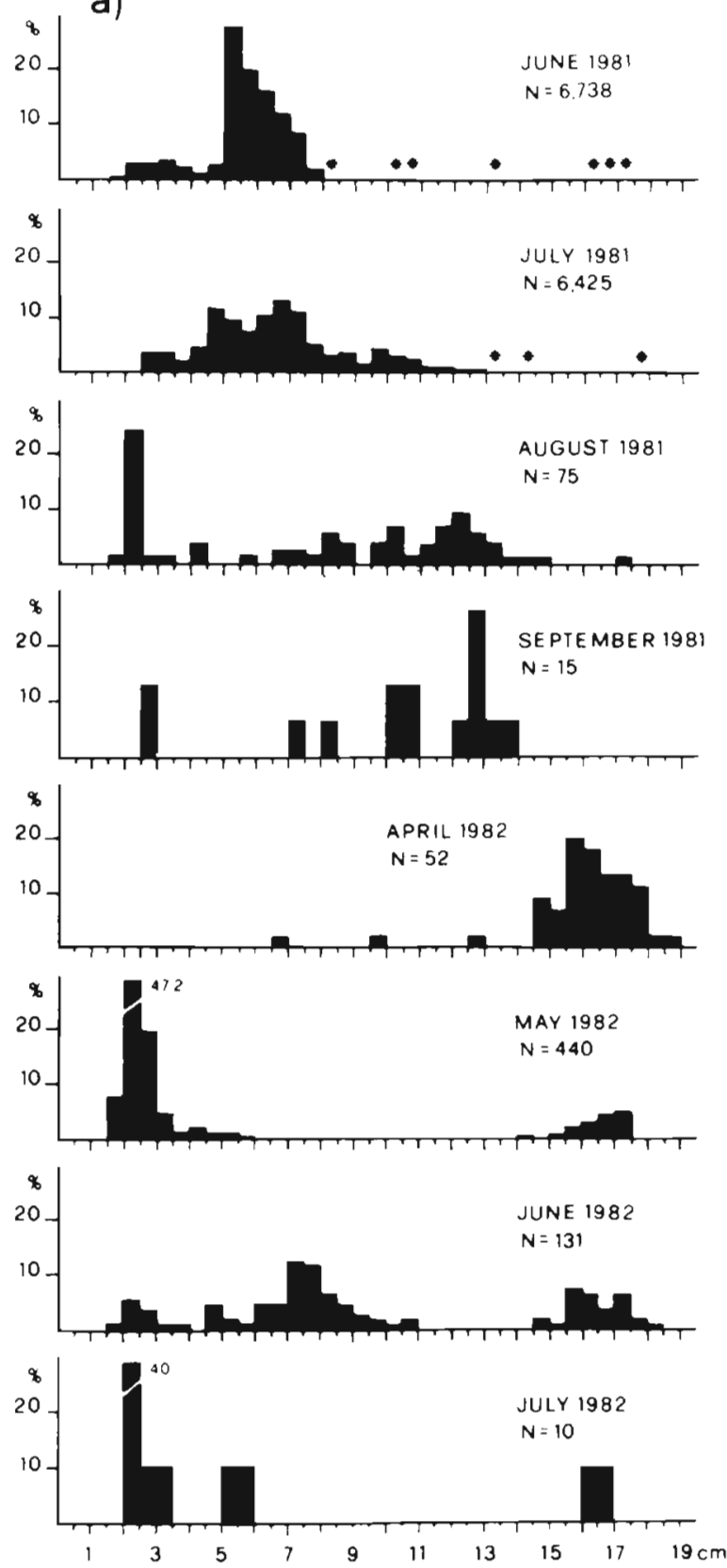

b)
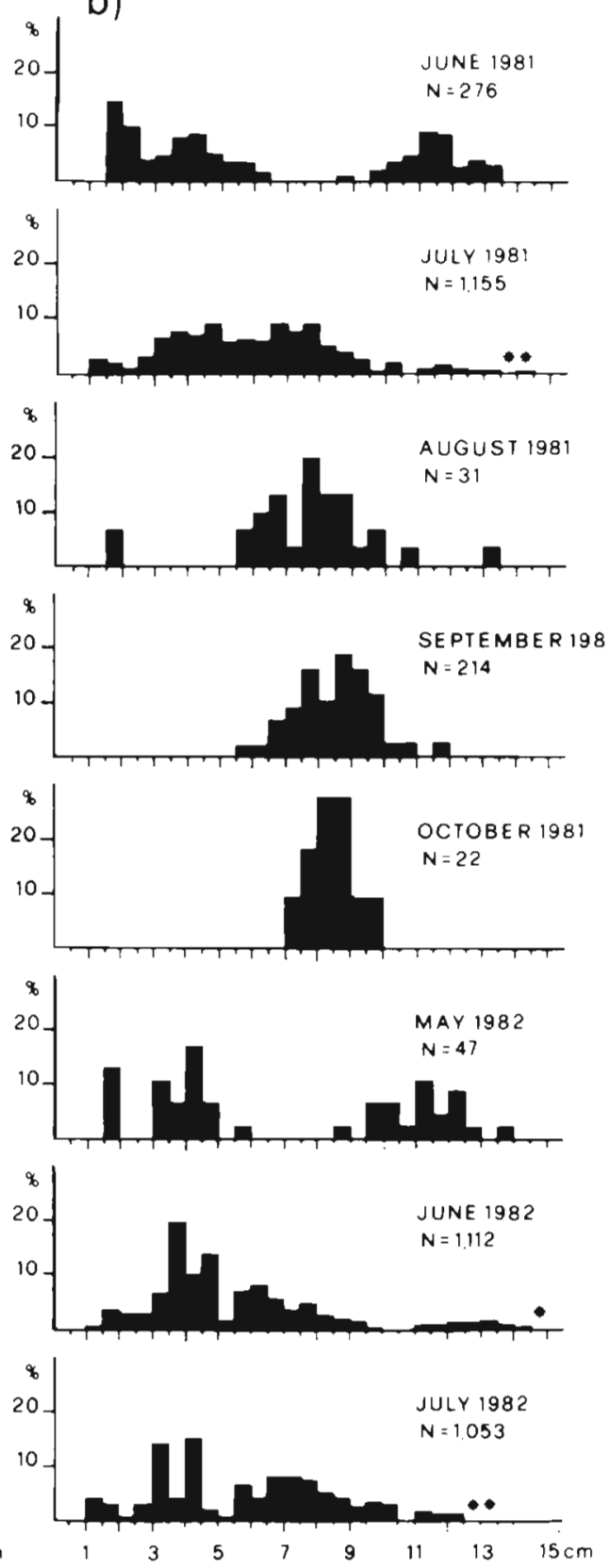

Fig. 2. Monthly per cent frequency distributions of standard lengths of (a) Syngnathus taenionotus and (b) $S$. abaster, N: number of specimens caught ${ }^{*}$ values less than $1 \%$

tive season and incubation period, estimated in the same way as for $S$. taenionotus, last about 4 mo and 1 mo respectively. Again, the highest abundance of recruits occurred in June-July.

The average percentage of females in the adult population ( $>8 \mathrm{~cm} \mathrm{SL}$ ) was $47.5 \%$, and the sex ratio was not significantly different from 50:50 $\left(\chi^{2}=1.183\right.$, not significant at $1 \mathrm{df}$ ). During May and June (1 mo before the recruitment peaks) the percentage of females in the adult population was $38.2 \%\left(\chi^{2}=0.747\right.$, not signif- icant at $1 \mathrm{df})$ and $45.0 \%\left(\chi^{2}=2.09\right.$, not significant at $1 \mathrm{df})$.

Unlike the other species, each male seems potentially capable of receiving eggs from only one female.

Ovaries of Syngnathus abaster, contrary to those of $S$. taenionotus, take up most of the abdominal cavity when they are mature, containing nearly exclusively ripe eggs, except a few thin layers of small oocytes lining the ovary wall. 
Table 3. Comparison between some life-history traits of Syngnathus species from Sacca di Scardovari

\begin{tabular}{|c|c|c|}
\hline & S. taenionotus & S. abaster \\
\hline Ovigerous females & Feb-end Jul & Mar-end Jul \\
\hline $\begin{array}{l}\text { No. of eggs/female } \\
\left(\text { mean } \pm \mathrm{SD}_{i} \mathrm{n}=60\right)\end{array}$ & $46 \pm 9$ & $104 \pm 40$ \\
\hline $\begin{array}{l}\text { Egg diameter }(\mathrm{mm}) \\
(\text { mean } \pm \mathrm{SD} ; \mathrm{n}=60)\end{array}$ & $1.4 \pm 0.2$ & $1.2 \pm 0.2$ \\
\hline $\begin{array}{l}\text { Female percentages during } \\
\text { reproductive peak }\end{array}$ & Apr: 15.7 - May: 11.4 & May: 38.2 - Jun: 45.0 \\
\hline Males with brood pouch & Mar-Aug & beg. Apr-end Jul \\
\hline $\begin{array}{l}\text { No. of male broods per } \\
\text { reproductive season }\end{array}$ & 2 & 4 \\
\hline $\begin{array}{l}\text { No. of eggs } / \text { male } \\
(\text { mean } \pm \mathrm{SD} ; \mathrm{n}=60)\end{array}$ & $84 \pm 17$ & $109 \pm 27$ \\
\hline Occurrence of juveniles & May-Sep (Oct) & May-Aug \\
\hline Egg incubation & $2 \mathrm{mo}$ & $1 \mathrm{mo}$ \\
\hline $\begin{array}{l}\mathrm{SL} \text { at birth }(\mathrm{mm}) \\
\left(\text { mean } \pm \mathrm{SD}_{\mathrm{i}} \mathrm{n}=35\right)\end{array}$ & $20.3 \pm 1.2$ & $13.5 \pm 1.0$ \\
\hline Life span & $\sim 20-24 \mathrm{mo}$ & $-13-17 \mathrm{mo}$ \\
\hline $\begin{array}{l}\text { No. of reproductive } \\
\text { seasons per lifetime }\end{array}$ & 2 & 1 \\
\hline${ }^{\circ}$ See text & & \\
\hline
\end{tabular}

Syngnathus abaster. The most important food items in the diet of 5 . abaster were harpacticoids of the genus Tisbe (Tables 4 \& 6). These are the most common representatives of the phythal meiofauna, chiefly associated with the Ulva thalli in the Sacca di Scardovari (Ceccherelli et al. 1982). Tisbe holothuriae and T. bulbisetosa were alternatively dominant prey in all seasons and in both cohorts, except the autumn 1-age specimens. A third species, $T$. histriana, was also well represented. Other meiobenthic harpacticoid species, as well as zooplanktonic copepods, occurred only sporadically, with the exception of Canuella perplexa, the most common benthic harpacticoid in the bay (Ceccherelli et al. 1982). This species was moderately preyed on by the 0 -cohort specimens in summer (Table 6). Amphipods, such as the phytal Gammarus insensibilis and Melita palmata and the mu-

\section{Feeding habits}

Syngnathus taenionotus. Results from the gut content analysis of $S$. taenionotus subsamples are shown in Tables 4 \& 5 .

The phytal harpacticoid Tisbe holothuriae and, to a lesser extent, $T$. histriana and $T$, bulbisetosa, dominated the diet of the 0 -cohort during spring, representing $95 \%$ of food items (Table 5). Subsequently, Syngnathus taenionotus appears to have fed on zooplanktonic organisms (Table 5). Calanoids such as Acartia clausi, A. latisetosa and, to a lesser extent, A. margalefi were particularly important in the diet of the 0 -cohort during summer, but also in that of the 1 -cohort during both spring and summer. Decapod Iarvae (zoea) were also intensively preyed on by juveniles in summer, and were the dominant prey of adults in spring and especially summer. As the seasons progressed and size increased, S. taenionotus (both cohorts) fed on larger zooplanktonic organisms. In autumn the diet was almost exclusively made up of the mysid Mesopodopsis slabberi (Table 5). This may have been a consequence of the low number of individuals with full gut found in the autumn samples. However, this prey-species was also well-represented at other ages/seasons, except in the 0 -age cohort during spring (Table 5). cous tube-dweller Corophium insidiosum, contributed to the diet of the larger-sized specimens (1-cohort), especially in autumn (Table 6). The remarkable amounts of eggs found in the gut contents of 1 -age specimens (Table 6) probably stemmed from gravid female gammarids. In S. abaster the corneus opercola of the polychaete Ficopomatus enigmaticus was recognized.

Table 4. General gut content composition from subsamples of Syngnathus species of the Sacca di Scardovari. Tn: S. taenionotus; $\mathrm{Ab}$ : S. abaster; Sp: spring; Su: summer; Au: autumn; 0 and 1. age-cohorts

\begin{tabular}{|cccc|}
\hline $\begin{array}{c}\text { Age/season } \\
\text { subsamples }\end{array}$ & $\begin{array}{c}\text { No. of } \\
\text { fishes }\end{array}$ & $\begin{array}{c}\text { Average no. of } \\
\text { prey pergut }( \pm \mathrm{SD})\end{array}$ & $\begin{array}{c}\text { No. of } \\
\text { food items }\end{array}$ \\
\hline TnSp0 & 30 & $117.73 \pm 56.94$ & 13 \\
TnSp1 & 30 & $16.13 \pm 6.80$ & 15 \\
TnSu0 & 30 & $81.13 \pm 21.20$ & 16 \\
TnSu1 & 30 & $205.47 \pm 139.09$ & 14 \\
TnAu0 & 6 & $2.67 \pm 0.75$ & 2 \\
TnAu1 & 11 & $8.45 \pm 0.50$ & 1 \\
AbSp0 & 30 & $42.40 \pm 11.37$ & 17 \\
AbSp1 & 30 & $59.73 \pm 38.69$ & 19 \\
AbSu0 & 30 & $62.20 \pm 24.61$ & 16 \\
AbSu1 & 30 & $21.17 \pm 23.16$ & 15 \\
AbAu0 & 30 & $27.93 \pm 18.47$ & 17 \\
AbAu1 & 30 & $9.80 \pm 5.88$ & 21 \\
\hline
\end{tabular}




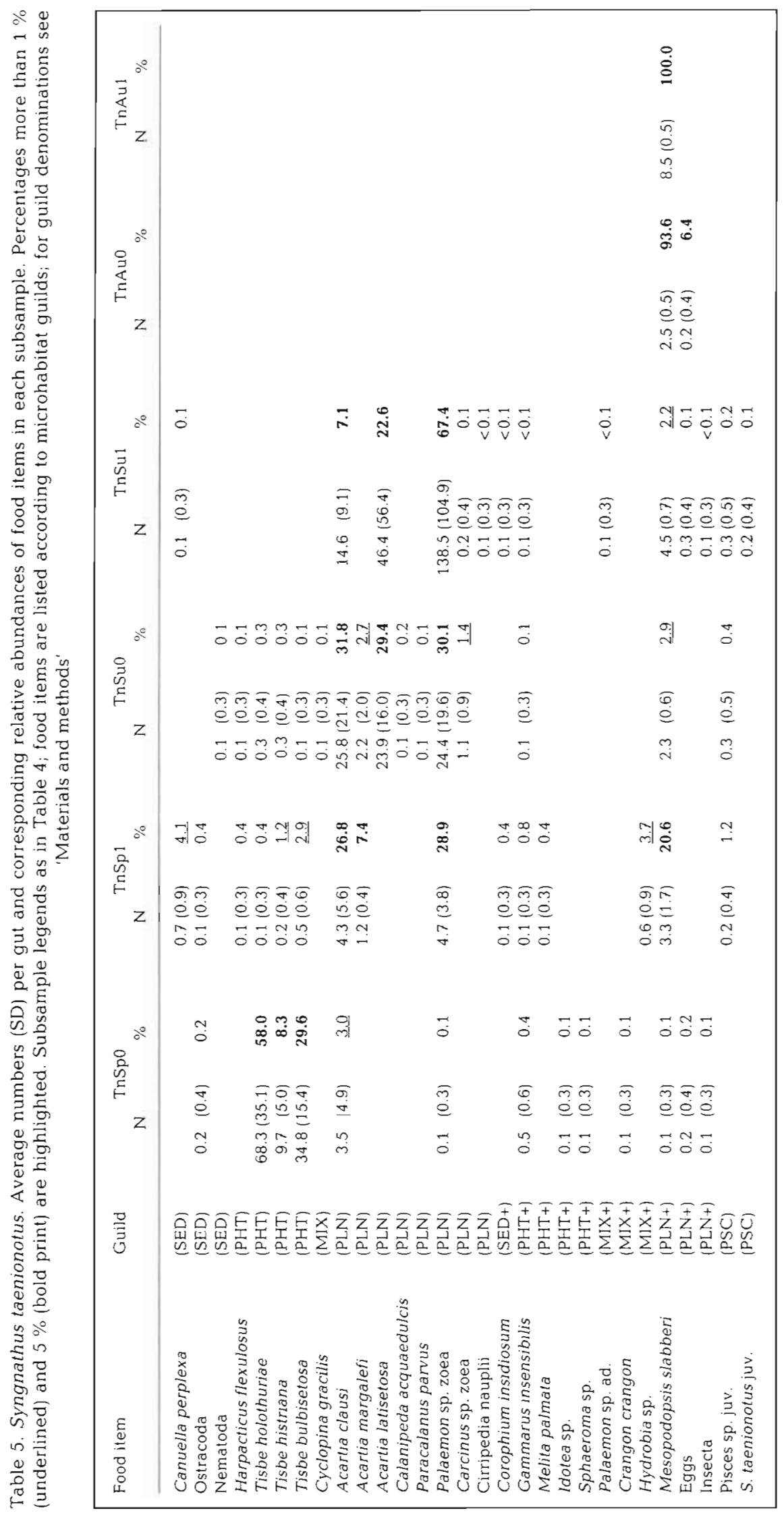




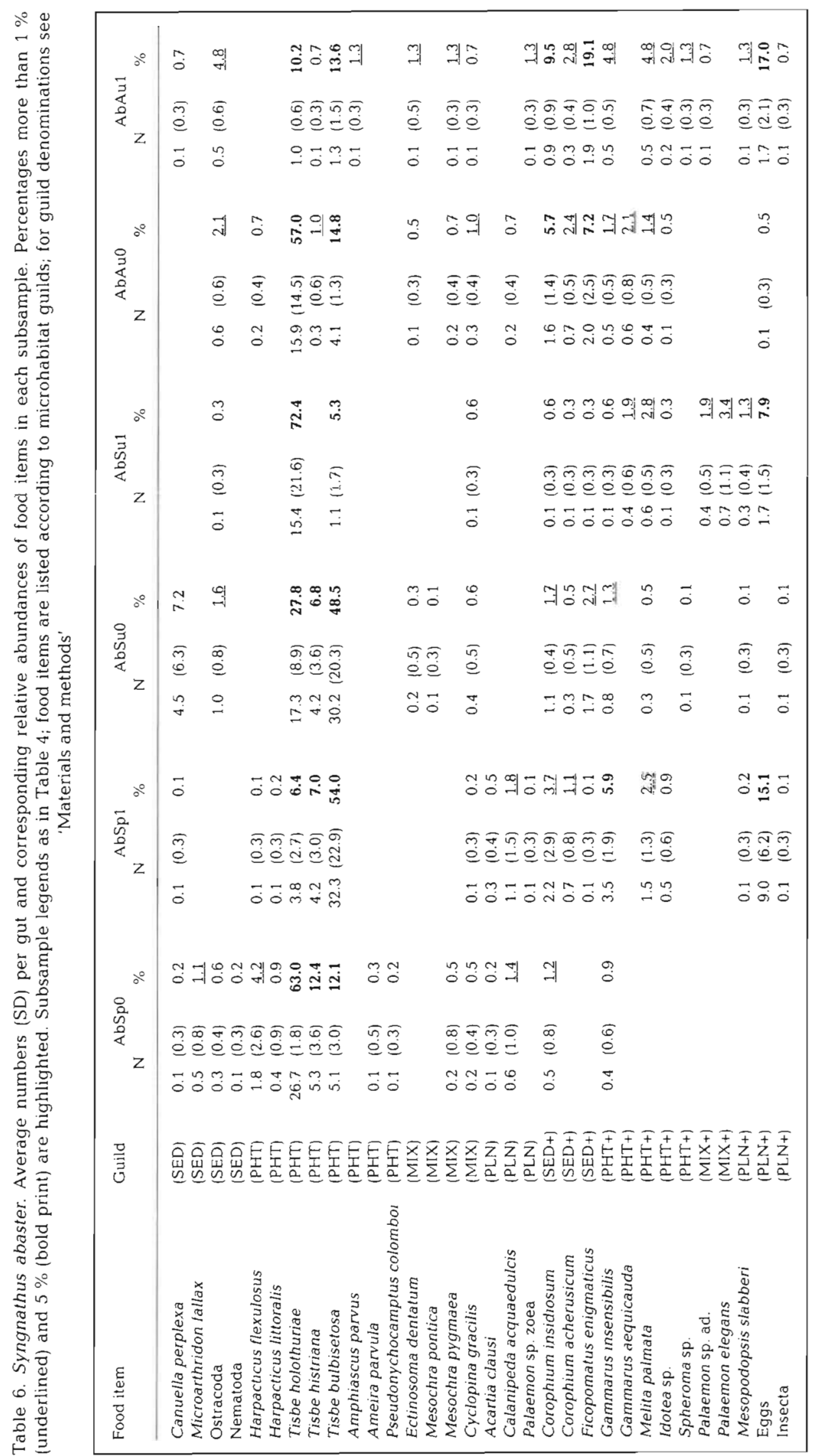




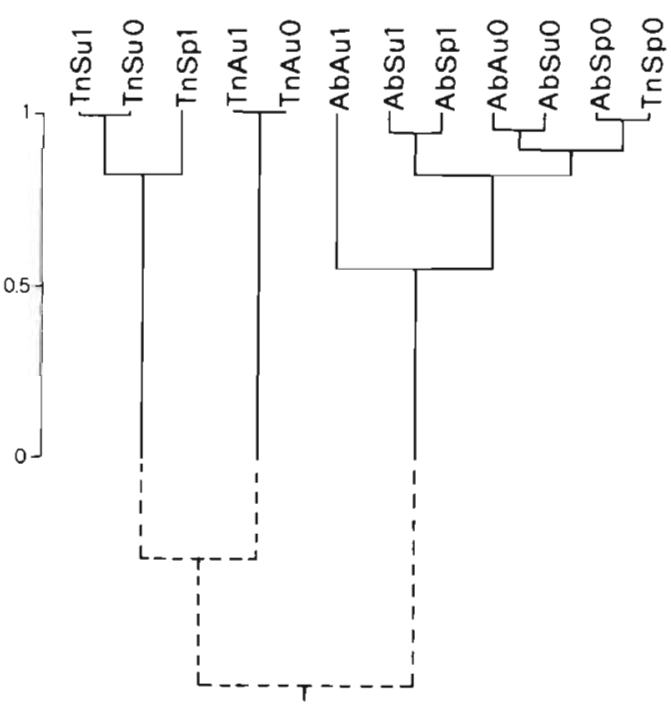

Fig. 3. Classification dendrogram of gut content subsamples of Syngnathus species based on the abundances of the preys grouped in microhabitat guilds. Tn: $S$. taenionotus; Ab: $S$. abaster; Sp: spring; Su: summer; Au: autumn; 0 and 1: agecohorts

\section{Foraging habitat comparison}

When food items were grouped by microhabitat 'guilds' as shown in Tables $5 \& 6,2$ species-specific clusters resulted (Fig. 3). The only exceptions were the spring subsamples of 0-age specimens of both Syngnathus taenionotus (TnSp0) and $S$. abaster (AbSp0), which show a very high similarity value. On the whole, the $S$. taenionotus cluster tended to be hierarchically ordered, first by season and then by age, whereas the reverse seemed to occur in the $S$. abaster cluster, suggesting the existence of some ontogenetic shifting in the diet of the latter species.

\section{DISCUSSION}

\section{Life cycle difierences}

Syngnathus taenionotus and $S$. abaster can be found together in the nearshore phytal habitat of the Sacca di Scardovari during their reproductive season. For both species reproduction begins in the spring of the first year. $S$. taenionotus probably reproduce twice in its lifetime, while $S$. abaster reproduce once. The 2 species appear to have somewhat different reproductive strategies. S. taenionotus produces a smaller number of large young while $S$. abaster produces more, but smaller young. Production of larger young in $S$. taenionotus, possibly to escape predation and favour feed- ing (Balon 1984), may necessitate its prolonged incubation period.

On the other hand, each single male of Syngnathus taenionotus can simultaneously take care of eggs from more than 1 female (in theory, at least 2) whereas the male brood pouch of $S$. abaster only has room for as many eggs as a female seems to produce at each spawning. However, in pipefishes, mating may not be on a 1 female: 1 male basis (Bayer 1980). In species of Syngnathus, females may parcel out the same batch of contemporary ripe eggs among many males, and embryos/postlarvae at different stages of development can be found in the pouch of a single male (Breder \& Rosen 1966, Bayer 1980, Berglund et al. 1988).

In pipefish populations the parental investment is also elevated for males, in many cases to the extent of causing a sex role reversal: i.e. males limit species reproduction (Bayer 1980, Berglund et al. 1986a, b, 1989, Svensson 1988, Steffe et al. 1989, Berglund 1991). In fact, in many syngnathid species, females appear to produce more eggs, or produce them at a faster rate, than naturally available males could care for. Moreover, there is an apparent association between mating pattern (polygamous or monogamous) and the sex roles in syngnathids (Vincent et al. 1992). The longer incubation period and more distinct polygamy of Syngnathus taenionotus compared to $S$. abaster might suggest a more pronounced sex role reversal in the former species.

During the breeding season, Syngnathus taenionotus males are more numerous than females; this is less pronounced in $S$. abaster (Table 3). It is possible that $S$. taenionotus females might have avoided sampling since they occupy habitats other than the phytal one close to the shore (Steffe et al. 1989). Svensson (1988) demonstrated in the laboratory that reproducing females of Syngnathus typhle had increased activity and a higher food intake compared with reproducing males. S. taenionotus females feeding mainly on planktonic prey may prefer to forage in deeper less vegetated habitats. In contrast, incubating males seem to seek shelter preferentially in the dense phytal habitat.

\section{Feeding habits}

Syngnathus taenionotus and S. abaster in the Sacca di Scardovari seem to feed on different prey. The only strong dietary overlap between the 2 species is during spring, when the newly born feed exclusively on phytal harpacticoids of the genus Tisbe. The importance of meiofaunal harpacticoids as a food source is well known for syngnathids (Tipton \& Bell 1988) as well as other small and/or juvenile fishes (Alheit \& Scheibel 1982, Gee 1989, Coull 1990). Harpacticoid dominance 
in the diet is not surprising, since harpacticoids are normally the dominant meiofaunal organisms in the phytal habitat of the Sacca di Scardovari (Ceccherelli et al. 1982).

Except for the newly born, individuals of the 2 species appear to occupy different foraging micro-habitats for most of their life span: Syngnathus abaster preys on phytal organisms whereas $S$. taenionotus becomes mainly zooplanktivorous. This suggests that $S$. abaster may remain within, or under, the phytal bed (Ulva thalli), whereas $S$. taenionotus may remain on top of the phytal canopy feeding on plankton that float by. Differential use of microhabitats in phytal environment has been demonstrated in syngnathid species by Howard \& Koehn (1985).

Both cohorts of Syngnathus taenionotus preyed mainly on calanoids and on decapod larvae during summer but exclusively on mysids during autumn. Concurrent zooplankton investigations carried out at the same stations (Ferrari unpubl.) showed that zoeae disappeared from plankton in September 1981 whereas calanoids, an average, reached the relative minimum $(1.7 \%)$ of their yearly density trend in October 1981. Mysids may be a less desirable prey, utilized only when other preferred prey was not abundant during autumn. A similar occurrence was described by Ryer \& Orth (1987) for Syngnathus fuscus. Other studies on species of Syngnathus (Main 1985, Ryer 1988) indicate that the abundance of prey types in the diet depends on the accessibility, or vulnerability, of the prey itself, as well as on abundance in the environment.

Both pipefish species investigated here are slowmoving suction feeders. We suggest that snout structure is related to their respective foraging strategies. Hyatt (1979) pointed out that, in general, the development of a long, tubular mouth, as in Syngnathidae and Fistularidae, serves as an adequate substitute to gillrakers for zooplankton feeding. According to Muller \& Osse (1984), who studied fish suction feeding thoroughly, the accuracy of aim required to catch a prey depends upon the total volume of the parcel of water sucked in as well as the length of the snout. In Syngnathids, the very rapid dorso-rotation of the head and the long snout allow a rapid acceleration of the snout tip towards the prey (Muller 1987). The velocity and acceleration of the water relative to the mouth aperture increase when the snout is longer (Muller \& Osse 1984), so it is advantageous to increase the snout length when very rapid swimming prey are to be captured. Syngnathus taenionotus has a long and terminally cylindrical snout, whereas that of $S$. abaster is shorter and conical (Fig. 1). These characteristics of the $S$. taenionotus snout suggest this species has a greater aiming ability. In a less complex habitat, such as the water column above the phytal canopy, free-swimming prey may escape more easily than prey crawling on substrates, such as algal leaves. A better aiming ability on the part of the predator is, then, an advantage in the former habitat. On the contrary, the shorter snout of $S$. abaster may be fitter on preying in a high-complexity habitat.

These considerations may explain why the new-born specimens of both species, with snout sizes not yet well-differentiated (Fig. 1), thrive well in the complex, phythal microhabitat foraging on the same kinds of prey.

Occurrence of dietary shifting to progressively larger prey has been described in syngnathid species (Livingston 1982, Ryer \& Orth 1987, Tipton \& Bell 1988), Syngnathus abaster shows a moderate change of its diet with increasing body size but this does not involve any ontogenetic change of foraging microhabitat. On the other hand, S. taenionotus specimens, as they mature, switch to the less complex microhabitat of the water column above algal beds, where they are probably more successful at capturing fast swimming prey. This switch from epiphytal to plankton feeding is accompanied by a morphological change: the snout elongates.

Acknowledgements. We thank Vittorio Gaiani and Gabriele Fozzati for assistance in sample collection. We are also grateful to A. Berglund and an anonymous referee for their helpful criticisms. Financial support was provided by funds from the Ministry of the University and Scientific and Technological Research for 'Research Projects of National Interest' (MURST $40 \%$ )

\section{LITERATURE CITED}

Abramson, N. J. (1971). Computer programs for fish stock assessment. FAO Fish Tech. Pap. 101: 1-154

Alheit, J., Scheibel, W. (1982). Benthic harpacticoids as a food source for fish. Mar. Biol. 70: 141-147

Balon, E. K. (1984). Pattern in the evolution of reproductive styles in fishes. In: Potts, G. W., Wooton, R. J. (eds.) Fish reproduction: strategies and tactics. Academic Press, New York, p. 35-53

Bayer, R. D. (1980). Size, seasonality and sex ratios of the bay pipefish (Syngnathus leptorhyncus) in Oregon. Northwest Sci. 54: 161-167

Berglund, A. (1991). Egg competition in a sex-role reversed pipefish: subdominant females trade reproduction for growth. Evolution 45 (3): $770-774$

Berglund, A., Rosenqvist, G., Svensson, I. (1986a). Mate choice, fecundity and sexual dimorphism in two pipefish species (Syngnathidae). Behav. Ecol. Sociobiol. 19: 301-307

Berglund, A., Rosenqvist, G., Svensson, I. (1986b). Reversed sex roles and parental energy investment in zygotes of two pipefish (Syngnathidae) species. Mar. Ecol. Prog. Ser. 29: 209-215

Berglund, A., Rosenqvist, G., Svensson, I. (1988). Multiple matings and paternal brood care in the pipefish Syngnathus typhle. Oikos 51. 184-188 
Berglund, A., Rosenquist, G., Svensson, I. (1989) Reproductive success of females limited by males in two pipefish species. Am. Nat. 133(4): 506-516

Breder, C. M., Rosen, D. E. (1966). Modes of reproduction in fishes. Natural History Press, Garden City, NY

Ceccherelli, V U., Cortesi, D., Fabbri, G. (1982). Dinamica stagionale di una taxocenosi ad Arpacticoidi di ambiente salmastro. Bull. Musei. Ist. biol. Univ. Genova 50: 151-155

Colombo, G., Ferrari, I., Ceccherelli, V U., Cavallini, G., Rossi, R. (1979). Fattori idrologici e struttura dei popolamenti planctonici e bentonici nella Sacca degli Scardovari. Atti Soc. Toscana Sci. Nat. Pisa Mem. P. v., ser. B 86: 41-47

Coull, B. C. (1990). Are members of the meiofauna food for higher trophic levels? Trans. Am. microsc. Soc. 109(3): 233-246

D'Ancona, U. (1934), Le specie mediterranee del genere Syngnathus. R. Comit. Talass. It. Mem. 210: 6-79

Dawson, C. E. (1986). Syngnathidae. In: Whitehead, P. J. P., Bauchot, M. L., Hureau, J. C., Nielsen, J., Tortonese, E. (eds.) Fishes of the north-eastern Atlantic and Mediterranean, II. UNESCO, Paris, p. 628-639

Ferrari, I., Chieregato, A. R. (1981). Feeding habits of juvenile stages of Sparus auratus L., Dicentrarchus labrax L. and Mugilidae in a brackish embayment of the Po River Delta. Aquaculture 25: 243-257

Ferrari, I., Rossi, R. (1983). Regime alimentare di Atherina boyeri Risso in una laguna del Delta del Po. Nova Thalassia 6: $275-280$

Franzoi, P., Trisolini, R., Carrieri, A., Rossi, R. (1989). Caratteristiche ecologiche del popolamento ittico ripario della Sacca di Scardovari (Delta del Po). Nova Thalassia 10 suppl. 1: 399-405

Gee, J M. (1989). An ecological and economic review of meiofauna as food for fish. Zool. J. Linnean Soc. 96 243-261

Horn, H. S. (1966). Measurement of 'overlap' in comparative ecological studies. Am. Nat. 100: 419-424

Howard, R. K., Koehn, J. D. (1985). Population dynamics and feeding ecology of pipefishes (Syngnathidae) associated with eelgrass beds of Western Port, Victoria. Aust. J. mar Freshwat. Res. 36: 361-370

Hyatt, K. D. (1979). Feeding strategy. In: Hoar, W. S., Randall, D. J., Brett, J. R. (eds.) Fish physiology, VIII - Bioenergetics and growth. Academic Press, New York, p. $71-119$

Lance, G. N., Williams, W. T. (1967). A general theory for classificatory sorting strategies. I. Hierarchical systems. Computer J. 9: 373-380

This article was submitted to the editor
Livingston, R. J. (1982). Trophic organization of fishes in a coastal seagrass system. Mar Ecol. Prog. Ser. 7 : $1-12$

Maccagnani, R., Carrieri, A., Franzoi, P., Rossi, R. (1985) Osservazioni sulla struttura di popolazione ed il ruolo trofico di tre specie di gobidi (Knipowitschia panizzae, Pomatoschistus marmoratus, Pomatoschistus canestrinii) in un ambiente del Delta del Po. Nova Thalassia 7 (suppl. 3): $373-378$

Main, K. L. (1985). The influence of prey identity and size on selection of prey by two marine fishes. J. exp. mar. Biol Ecol. 88: 145-152

Muller, M. (1987). Optimization principles applied to the mechanism of neurocranium levation and mouth bottom depression in bony fishes (Halecostomi). J. theor. Biol. 126 343-368

Muller, M., Osse, J. W. M. (1984). Hydrodynamics of suction feeding in fish. Trans. Zool. Soc. Lond. 37: 51-135

Quignard, J. P. (1984). Les caractéristiques biologiques et environnementales des lagunes en tant que base biologique de l'aménagement des pêcheries. FAO - GFCM Etudes et Revues 61(1): 3-38

Rossi, R. (1986). Occurrence, abundance and growth of fish fry in Scardovari Bay, a nursery ground of the Po River Delta (Italy). Arch. Oceanogr. Limnol. 20: 259-280

Ryer, C. H. (1988). Pipefish foraging: effects of size, prey size and altered habitat complexity. Mar. Ecol. Prog. Ser. 48: $37-45$

Ryer, C. H., Orth, R. J. (1987). Feeding ecology of the northern pipefish Syngnathus fuscus in a seagrass community of the lower Chesapeake Bay. Estuaries 10(4): 330-336

Ryer, C. H., Boehlert, G. W. (1983). Feeding chronology, daily ration, and effects of temperature upon gastric evacuation in the pipefish, Syngnathus fuscus. Environ. Biol. Fish. 9(3/4): 301-306

Steffe, A. S., Westoby, M., Bell, J. D. (1989). Habitat selection and diet in two species of pipefish from seagrass: sex differences. Mar. Ecol. Prog. Ser. 55: 23-30

Svensson, 1. (1988). Reproductive costs in two sex-role reversed pipefish species (Syngnathidae). J. Anim. Ecol. 57: 929-942

Tipton, K., Bell, S. S. (1988). Foraging patterns of two syngnathid fishes: importance of harpacticoid copepods. Mar Ecol. Prog. Ser. 47: 31-43

Vincent, A., Ahnesjo, I., Berglund, A., Rosenqvist, G. (1992). Pipefishes and seahorses: are they all sex role reversed? TREE 7: 237-241

Manuscript first received: April 6, 1992

Revised version accepted: March 22, 1993 